\title{
Reflections on the Politics of Power Patriarchy in Vietnamese Gender Employment
}

\author{
Thi Loan Lam ${ }^{1} \&$ Ron Laura ${ }^{1}$ \\ ${ }^{1}$ School of Education, The University of Newcastle, NSW, Australia \\ Correspondence: Thi Loan Lam, PhD student, School of Education, The University of Newcastle, NSW, \\ Australia.
}

Received: October 10, 2016

Accepted: November 1, $2016 \quad$ Online Published: November 15, 2016

doi:10.20849/ajsss.v2i1.81

URL: http://dx.doi.org/10.20849/ajsss.v2i1.81

\begin{abstract}
The advent of Feminism, and the philosophical ideas it has engendered, have impacted significantly to improve 'gender equality', especially in the western world. However, such ideas represent relatively new, and from the public's perspective, unconventional concepts in Viet Nam. There is still a very strong underpinning of Confucianism which pervades and shapes community perspectives on the roles which women should and should not play. Nonetheless, a burgeoning governmental awareness of the depth of the problem of covert gender inequity is slowly but steadily surfacing, along with legislation that has encouraged and supported an increasing number of women to undertake education and employment at the tertiary level. Despite the admirable efforts of the government, there exists a cultural phenomenon of blatant inequity, now known popularly as the "glass ceiling effect" (i.e., a transparent structural barrier which compromises the spirit of equity which would otherwise afford women with the same opportunities to executive appointments in many areas of executive leadership as extend to men. The study presented here about the access women have to executive positions in Tertiary Education shows clearly that despite the fact that many women are as professionally qualified as the male applicants with whom they compete, there are significantly fewer women in executive tertiary employment than men.
\end{abstract}

Keywords: patriarchy, leaders, higher education, equity, gender

\section{Introduction}

Although there are many facets of pervasive gender discrimination in Vietnam, the aim of this paper is to restrict our analysis to a more specialised but manageable aspect of this larger problem. Our goal is to elucidate a range of discriminatory factors which specifically disadvantage females from passing through the 'glass ceiling' where it relates to women gaining senior educational leadership positions in Viet Nam. In the light of growing public awareness of these intractable barriers, the Vietnamese government has, to its credit, recently issued a rudimentary legislation to protect the equal rights of women. Although the Vietnamese government has admirably fostered this legislative policy to protect women's rights, we shall see that the hidden socio-cultural agenda of Confucianism and its discriminating stance on equal rights for men and women is one major factor which has served as an impediment to women breaking through the 'glass ceiling' to secure senior leadership positions in tertiary education. We shall also see that another dimension of the problem of gender inequity relates to what Laura has in a number of publications called the "patriarchal epistemology of power" (Webster \& Laura, 2016; Laura \& Chalender, 2012; Buchanan \& Laura, 2012).

Lest we be misunderstood, there is no doubt that governmental legislation aimed at improving gender equity has advanced the status of women in Vietnamese society. Legislation has served to provide a positive step forward that has to some extent resulted in affording women more opportunity to participate in social activities, and gain some job opportunities previously otherwise reserved for men (Australia, 2013). However, compared to men, the number of Vietnamese women in senior positions in tertiary institutions is still disconcertingly low, especially in higher education. Our aim is to determine the extent to which the underlying philosophy of Confucianism and patriarchal epistemology have so embedded traditional Vietnamese norms and values, that female leadership in higher education remains seriously compromised. 


\section{Background}

To understand what is occurring in Vietnam, it is important to appreciate that the current problem of gender inequity is not an anomaly peculiar to Vietnam. For example, in 2015 United Nation adopted the Sustainable Development Goals (SDGs) for addressing gender equality and empower all women and girls in 2030. It was intended that the particular objectives and goals of SDGs would be achieved by 2030. Goal 5 in SDGs was concerned to: "Achieve gender equality and empower all women and girls"- with the subtitle that opines, “"'Ensure women's full and effective participation and equal opportunities for leadership at all levels of decision making in political, economic and public life". (UN, 2015, p. 18)

Although more women in Vietnam are now taking advantage of educational opportunities such as leadership positions in the context of higher education, gender equity in higher education is still an issue in many countries across the world. In Australian universities, for example, $70 \%$ of leadership positions are held by men, with only $30 \%$ of women occupying the same level of leadership appointments (Lord \& Vinnicombe, 2010). In Germany, the proportion of full female professors was 23\% in 2015 (Thomas, 2016). It is clear that the employment of women in executive decision-making positions is underrepresented in most countries. According to a report from the World Bank (Dollar \& Gath, 1999), the measure of gender equality in developing countries continues to be worse than in developing countries. Men, for example, enjoy greater access to legal rights which assure them property appropriation, along with greater control over women in the home and in the organisations where they may be working (World Bank, 2001). Furthermore, even where the qualifications of women and men are essentially the same, the remuneration for women doing the same job is less than the remuneration paid to men (Goldin, 2013).

Despite the noble efforts and intentions of MDGs, the world still remains rife with poverty, and the discrepancies in the consideration of interest between men and women in virtually all cultures, developing and developed, is organised to favour men's rights in practice, not women's rights.

\section{The Philosophical Context of Viet Nam}

\subsection{Confucianism}

Given that Viet Nam was occupied by the Chinese for approximately a thousand years, Confucianism was adopted as a philosophical worldview. This being so, Confucianism consequently featured as an official ideology. In the feudalist organisation of Vietnamese society The impact of Confucianism in the sociocultural evolution of Viet Nam has been significant, and one aspect of its influence has affected gender relations in Vietnam. Within the context of Family Confucianism its philosophy gave birth to a "patriarchal hierarchy" in which men exerted massive control and dominance over women. Men were regarded as the Head and Patriarch of the family, and thus the arbiter of its social activities, while women were regarded as being in charge of domestic chores. There is a Confucianist proverb that says "having a son means having everything, while having ten daughters means having nothing" (Nguyen, 1995). Being born female, the daughters have strict obligations to obey their parents, and are expected to help with every aspect of the housework. When they get married, however, they become part of their husband's family, and belong only to their husbands. When women become widows, their eldest son decides what they can do and want.

In general Vietnamese women have limited rights to make official decisions about participating in higher education. Despite the progress towards gender equity made in recent years, the role which Vietnamese women play in determining their academic careers is virtually defined by the head male in their family, and it is within the family that the psyche of the male is in large part still primarily characterised by the Confucianist stereotype of women as inferior to men. Vietnamese women, whether they work or not, still feel the need to take responsibility for virtually all household chores and family activities, including such things as arranging household budgeting and the early education of their children (Binh, Van \& Khieu, 2002. Other studies have shown that in those cases where men and women are jointly responsible for domestic chores, husbands share only about $20 \%$ of the household work (Houtrat \& Lemercinier, 2004). It is clear that the pervasiveness of Confucianism with its deeply entrenched patriarchal persuasion, has been underestimated in regard to its capacity to create barriers to success which inevitably disadvantage and discriminate against women on many levels, while simultaneously advantaging the male gender in employment with easy access to sociocultural opportunities for status and pecuniary benefits.

\subsection{The Evolution of Gender Equity in Vietnam}

During Vietnam's war of independence and their endeavour to emancipate themselves from the French, the Vietnamese government significantly elevated the status of women by officially honouring the substantial contribution they made to the war effort. Strong praise was showered upon the women of Viet Nam for their involvement in various aspects of the overall war enterprise, such as military- decoding, translation and strategic 
planning. Support network activities were carried out such as raising and gathering crops for food provision and cooking; uniform manufacture and cleaning; book keeping, organisation of social activities, care of the family, and for some women, even their own enlistment in military service. Together with Vietnam's successful August Revolution and the concomitant creation of its new Constitution in 1945 with its explicit statement that "Men and women are equal in all domains of life", the issue of gender equity was for the first time addressed officially.

Given the Vietnamese government's formal acknowledgement of the contribution of women to the war effort, and the signing of equity-oriented MDGs between the Vietnamese government and other countries, more gender legislation to protect women's rights was passed by the government. This enlightened legislation included: the Gender equality law in 2001, the Gender Equality Law and Anti-domestic Violence Law in 2006, and the National Strategy for the Advancement of Women in 2010. Article 4 in the Decision 73/2006/QH11, dated 29 September, 2006 represented a bold and determinate affirmation from the Vietnamese government of its rigorous and sincere stance on the paramount importance of achieving gender equity in Vietnam. The government declaration is as follows:

“Article 4. Gender equality goals

"The gender equality goals are to eliminate gender discrimination, to create equal opportunities for man and woman in socio-economic development and human resources development in order to reach substantial equality between man and woman, and to establish and enhance cooperation and mutual assistance between man and woman in all fields of social and family life" (The National Assembly, 2006)

"Gender equality indicates that man and woman have equal position and role; are given equal conditions and opportunities to develop their capacities for the development of the community, family and equally enjoy the achievement of that development." (The National Assembly, 2006)

To help foster the implementation of the 2006 Law, the Ministry of Labour, Invalids and Social Affairs (MOLISA) recently developed the National Strategy on Gender Equality for the period 2011-2020 and the National Programme on Gender Equality (2011-2015). One of their objectives is "to enhance the leadership and direction of party committees and authorities at all levels." It is imperative to recognise that not only has the Vietnamese government provided an admirably enlightened and inspiring legislative commitment to the goal of gender equality, but it has also issued other reports as referred to above which acknowledge and promote the integral value of the potential leadership contributions women are capable of making to the Vietnamese economy. It is clear that women's participation in the "socialist-oriented market economy" has helped Vietnam to be amongst the countries with the highest GDP growth in the world (Cox, 2013). Given the gender equity legislation introduced by the Vietnamese government, and their recognition of the importance of the potential role female leadership can play in improving the economy, it is ironic that the goal of gender equity and employment of women in executive leadership positions, especially, in tertiary education, have not been more successful. Indeed, despite the impressive gender equity legislation implemented by the Vietnamese government, the lamentable truth is that the situation has paradoxically deteriorated, and continues to decline. Recent research has accumulated to monitor and measure comparatively the hierarchical placements of successful gender equity as they pertain to countries around the world. A ranking of number ' 1 ' indicates the highest level of gender equity, with lesser success status ascribed to different countries in descending order. In 2007, Vietnam ranked 42nd in the world in terms of the equity gender gap index, only one below Switzerland, with countries such as Bangladesh, China, Thailand, France and the Russian Federation far below Vietnam. However, by 2011, these same countries which were raked far below Vietnam have all surpassed it. In 2011, only four years after its commendable gender equity ranking, Vietnam was 71 in the world rankings (UNDP, 2012). It was just two years later in 2013 when Vietnam's ranking dropped another 2 points to 73 in the world. The lower rankings are intended to reflect the increasing loss of women's access to power decision-making processes, and less leadership influence in both contexts of their community and workplace environments. The decline in Vietnam's position of ranking also reveals unequivocally that the proportion of female leaders is lower than male leaders across virtually all employment levels (UNDP, 2014; See also World Economic Forum, 2013).

\subsection{The Issue of Gender Equity in the Context Political Participation}

To understand the equity issues associated with women's participation in the National Assembly we need to know about the role this political instrument plays. The term ' National Assembly' refers to Vietnam's legislative body which is the highest standing body and the most powerful state office in Vietnam. Notwithstanding government legislation for gender equity and equal opportunity leadership, it is disappointing that the leader is still called the 'Chairman', not the 'Chairperson'. The point of emphasizing the disparity in the use of these words is that the way in which we describe something is in essence a commentary on how we conceptualise the things we describe. So the term 'Chairman' is not subliminally very welcoming to women, as the designation of 
the post covertly implies that it is Reserved for men. With this caveat in mind, notice that there are 122 female representatives in the National Assembly, thus occupying 24.4\% of its constituency in term XIII (Figure 1). This percentage figure reflects the monumental progress made by the government's initiative program in gender equality, with an astonishing improvement towards the equitable representation of women in the National Assembly, compared to the first term of office in 1946-1960, in which females occupied only $3 \%$ of this political body. However, compared to the 3 previous terms, including terms X, XI, XII, the female percentage figures have not continued to improve, as one might have expected, but have instead declined slightly (See Figure 1).

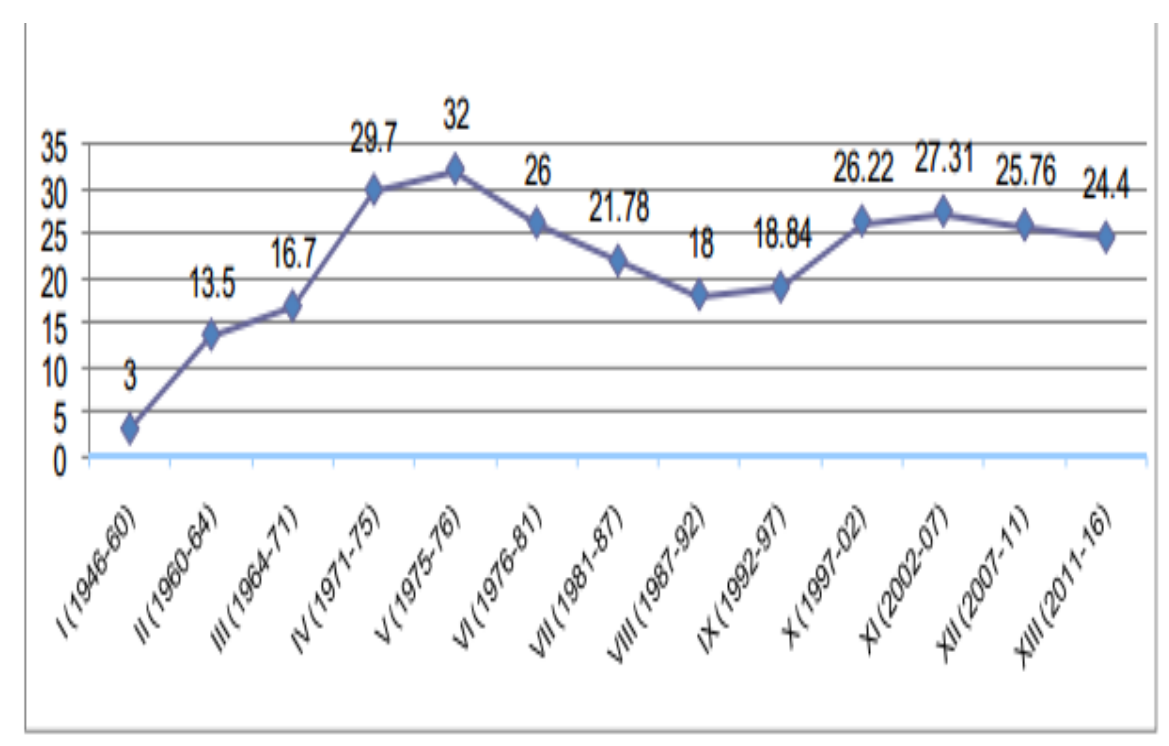

Figure 1. Percentage of women in the National Assembly; Source: UNDP (2012)

From the perspective of gender equality, the equity picture is even more dismal, inasmuch as the percentage of female constituents in all levels of government is less than it is for their male counterparts. In Figure 2, below you will notice that the green color, red color and blue color lines represent the percentage of females in the role of Director, Deputy Director, and male leaders in all levels of government office respectively.

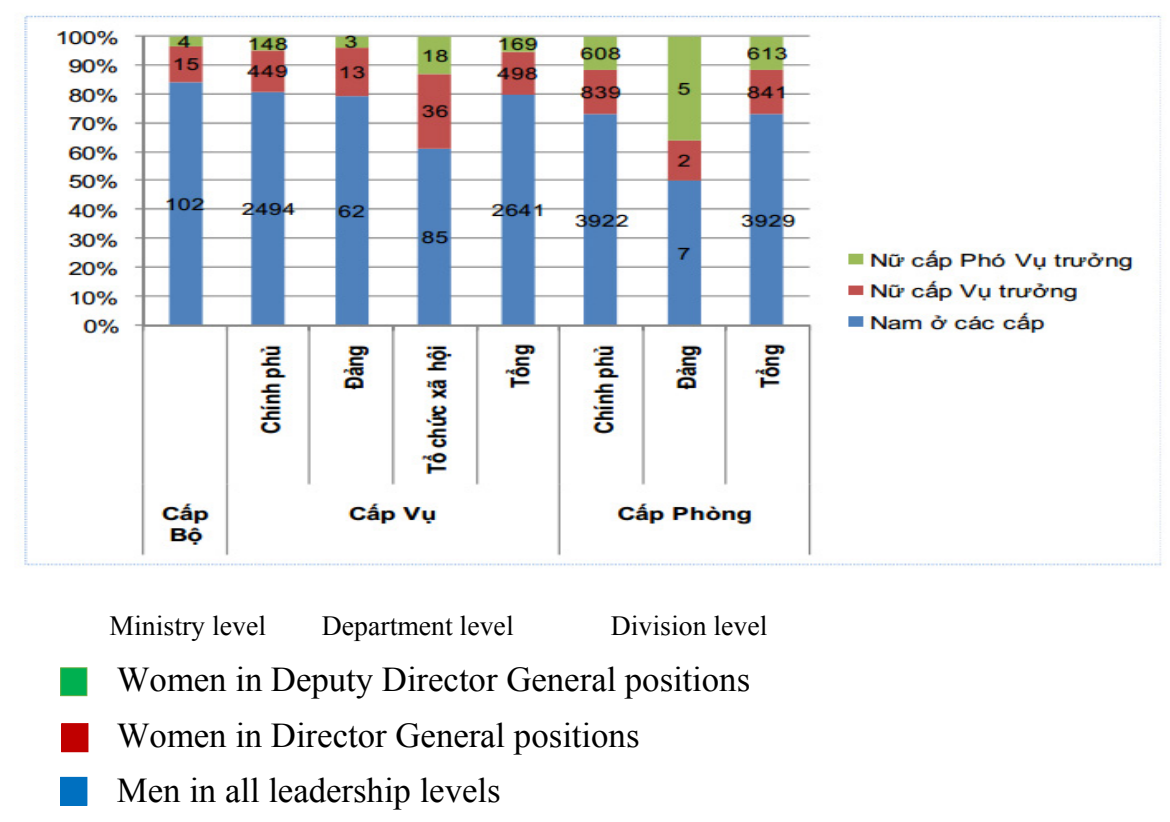

Figure 2. Percentage of female and male leaders at all levels in the Vietnamese government (UNDP, 2012) 
From this graph it can be inferred that equal opportunity and equitable access for women to the decision-making power positions in most of the existing Vietnamese management levels is illusory. Women are still disadvantaged in achieving their career goals, because they are excluded from the equal opportunity processes for employment that they were promised. The percentage of women in leadership positions is not improving and actually seems to be slowing down.

\subsection{Gender in Leadership: Reflecting on Women in Higher Education}

It is clear that in decades passed, there has been some very impressive progress, largely through the initiatives of the Vietnamese government, in achieving gender equality. Although the view of women's rights within and without the family in Vietnam is still covertly influenced by Confucianism, particularly in Education, and was a few decades ago one of the poorer countries in the world (World Bank, 1995; Tan \& Mingat, 1992) the literacy rate of females is currently quite high compared to other Asian countries. Similarly, the discrepancy between men and women in education is smaller than in the $19^{\text {th }}$ century. In a survey of 12 countries, the female adult literacy for Vietnam was $91 \%$, and just stands behind the Philippines and Thailand with $94.4 \%$ and $93.5 \%$ respectively (Figure 3). The adult literacy rate in Vietnam climbed to 95.4\% in 2011 (UNESCO, 2013, p.33) and increased slightly by 2015 (UNESCO, 2013, p.130).

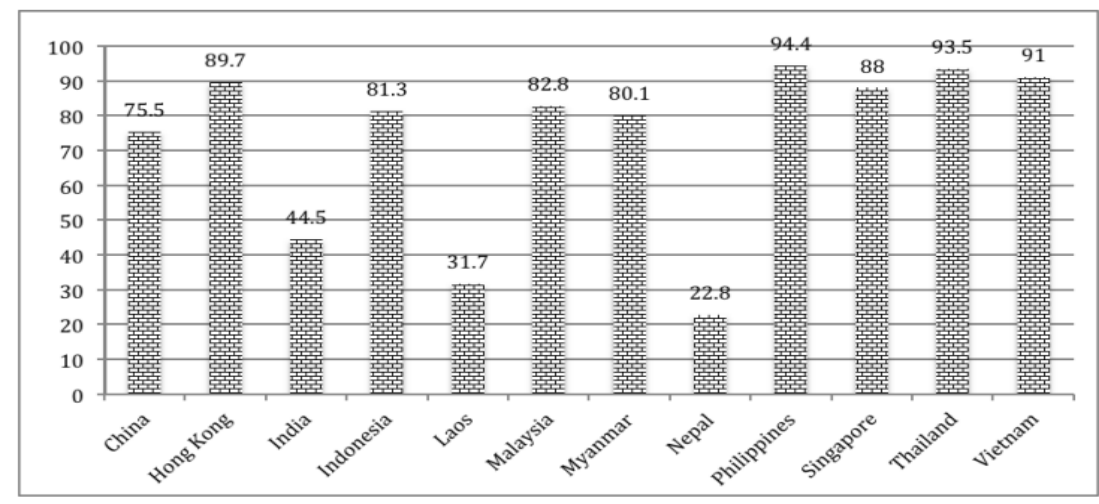

Figure 3. Literacy rate of females in different countries (UNESCO, 2013)

In addition to government support for public higher education universities, the government has also been encouraging the expansion of private universities and foreign universities since at least 2005 (Table 1).

Table 1. Number and type of higher education institutions in selected countries in 2012

\begin{tabular}{lrrr}
\hline Country & Public & Private & $\begin{array}{r}\text { of which branch campuses of } \\
\text { foreign universities }\end{array}$ \\
\hline Cambodia & 34 & 57 & 1 \\
China (2011) & 1.887 & 836 & 13 \\
Indonesia & 83 & 2.818 & - \\
Korea, Rep. & 61 & 350 & 2 \\
Lao PDR & 22 & 77 & - \\
Malaysia & 20 & 491 & - \\
Philippines & 220 & 1.636 & 16 \\
Singapore & 4 & 31 & 2 \\
Thailand & 98 & 71 & 1 \\
Viet Nam (2011) & 187 & 28 & \\
\hline
\end{tabular}

Source: (UNESCO, 2014) 


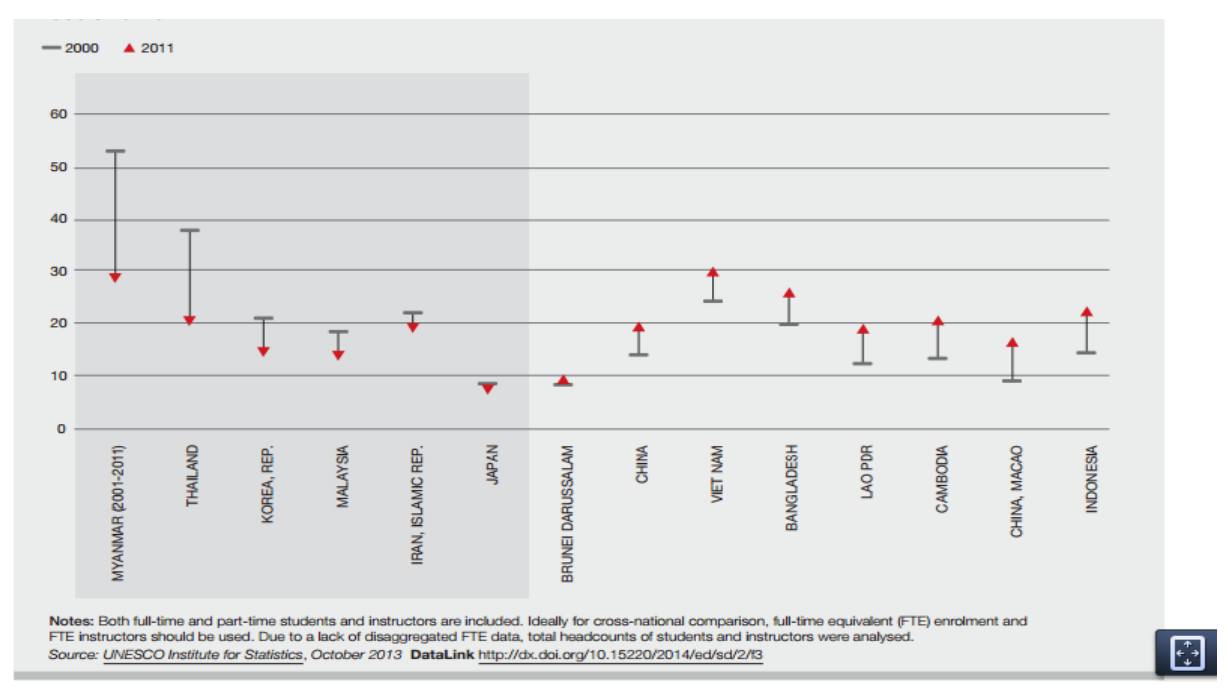

Figure 4. Student -instructor ratio in higher education Institutions in selected countries, 2000-2011(UNESCO, 2014)

Compared to neighboring countries, the student-instructor ratio in Vietnam has increased considerably from 2000 to 2011 (Figure 4). This ratio can be regarded in part as a result of the Vietnam's need for socially required skills. Indeed, having a university degree is believed to be an initial step to procuring a high paid job and ensuring a satisfactory standard of living (Carnoy et al., 2012; World Bank, 2012). Furthermore, the Vietnamese government has created opportunities and encouraged their citizens to obtain a postgraduate degree thereby expanding their qualifications and thus increasing the likelihood of realising the benefits of a better lifestyle. As a result, the number of students at both undergraduate and postgraduate levels and instructors has increased dramatically.

Needless to say, the increased population of tertiary students has in turn created a demand for more university teaching staff at instructor and lecturer levels, thereby affording new teaching opportunities for women.

According to the Ministry of Education and Training (2013), the total teaching staff in higher education institutions in the school year $2007-2008$ is 17.903 , of which 8.796 teachers are female. That figure increased significantly in the school year 2012 - 2013 with 61.674 teaching staff, and 29.194 female teachers.

Despite improving the access pathway to higher education teaching, the number of women who are successful in moving up to executive promotion is considerably less than their male counterparts, even when they have the same qualifications (UNESCO, 2014). The data from MOET (the Ministry of Education and Training) show that although the female teaching staff occupies two-thirds of the total educational staff, males are still usually appointed to the head positions within their educational institutions. The percent of female rectors, deputy rectors, faculty deans and school heads is limited, as has been shown from a survey of 53 public Universities in 2004. (USAID, nd)

\subsection{Obstacles Discussion}

Although there have been a number of programs and campaigns in Vietnam to educate husbands and wives, and sometimes their families, to understand the importance of sharing household responsibilities equally, this initiative has done little to reduce domestic labor sufficiently to provide time for women to access educational and even employment opportunities. In Vietnam the head of the family is still regarded as a Patriarch, and Patriarchy is linked to Paternalist epistemology which affirms that the Patriarch knows what is best for his family, especially his daughters who become defined as perpetual children in need of the father's alleged 'wisdom'. Because the power pedagogy of Paternalist epistemology represents a vested interest which reproduces itself, it becomes socioculturally embedded as having a monopoly on truth. Thus, the shibboleth 'Father Knows Best' is entrenched as a foundational value which has become fossilised. This is why it is has been so difficult to break the strangle hold which Confucianist stereotypical conventions play in stipulating a women's role in the home where she serves the vested interests of the Patriarchal Husband who cannot be challenged (Laura, Patriarchal Theism, 2012; See also Webster and Laura, Secularising the Sacred. Moreover, the results of some 
studies have shown that even for the community of women who have managed to emancipate themselves sufficiently from household responsibilities to find employment, there are still major obstacles that serve to impede the likelihood of their being promoted, especially into political and tertiary educational leadership positions (Nguyen, 1995). The stereotypical view of a woman's place in the home has become so ideologically entrenched in Vietnam that it has come to serve as a sociocultural barrier which has impacted adversely on many women. Many women are made to feel ashamed that they will no longer be staying at home to look after their children and focus full time on their household responsibilities. Without the barrier of stereotypic pressure which idealises their sense of obligation to be fully responsible for household management, many potentially intellectually talented women would otherwise be motivated to extend their education and seek forms of employment better suited to the realisation of their gifts. Once their confidence in themselves is confirmed, they will be much more likely even to be ambitious enough to strive for career promotion.

Let us now consolidate this part of the discussion. One of the most destructive barriers to gender equity is that deeply embedded and covert sociocultural conventions about the priority of a women's household obligations serve as a paralysis of intellectual imagination over their identity and what they could have been. A study by Tu et al. (2006) reveals that the Confucianist philosophy which characterises the place of women as being restricted to household management has become a presumptive value inextricably woven into the foundational fabric of the Vietnamese system of belief. Women are thus made to feel inferior to men in virtually everything they do outside the realm of their household obligations. Women are themselves led to believe that family and household chores are more important than salaried work, so there is no point in their seeking employment. The presence in Vietnam of this demoralising and restrictive facet of espoused gender inequity within Confucianism is reiterated within the early schooling context in which many textbook pictures reinforce cultural norms of women rearing their children and taking care of their household obligations. Given that many of these books feature women exclusively in the familial context of cooking, cleaning, and looking after their children, the misleading impression is conveyed that household management is actually the primary career for women (Binh, Van, \& Khieu, 2002).

Another barrier to gender equity is that given the stereotypic presumptions about women covertly embedded in the Vietnamese value system, woman who actually make it to the workplace are more rigorously evaluated than are males (John, Loi, Jayakodi \& Huy, 2004). One reason for this is that the people who evaluate their performance have themselves been influenced by the stereotypical descriptions drawn from the hidden agenda of Confucian value beliefs that regard women as inferior to men. Career promotion for women in Vietnam depends primarily on whether the views of women held by executive leaders, most of whom are men, comprehend the rationale for gender equality, held consciously or unconsciously to discriminate against women as the 'weaker sex' and thus already judge them as intrinsically inferior. Attitudes of this kind which are more common in Vietnam than one might expect constitute a psychological barrier on the part of their executives which are difficult to transcend, thus limiting women in accessing and fulfilling their potential leadership roles.

Another aspect of the glass ceiling barrier is the sociocultural phenomenon of 'epistemological patriarchy. On this view the knowledge assumptions men in power make are designed to support the vested interests of the ' Ole Boy Network' of which they are a part. If the dominant group of executors are male, then the vested interests of power are most effectively implemented by relying on and therefore preserving the bonds of male loyalty they know they can trust. Admitting a woman into that circle of trust is regarded as threatening because the epistemic primitive that defines the concept of loyalty is that you cannot trust a woman as you would trust a man.

Another potential barrier to gender equality derives from the 'policy of renovation' which entails the shift from state sector economy to 'open door' market economy. In a study conducted in China it was established that the 'gender division' of labour has increased in society since the transition from economy to market transition (Xie \& Hannum, 1996). This situation is similar to what has happened in Vietnam. It has been determined that the status of women has been eroded since the shift to market economy (Asian Development Bank, 2002). Policies including reducing budgets from the state sections, coupled with reducing day care services such as: subsidies for childcare, health care, family duties, and education have prompted an increase of labour division that shifts household chores already shared by husband and wife toward women who now pick up more of the burden. Furthermore, most private agencies now limit their recruitment of women, because they will lose a potential expenditure in regard to women's child rearing and child bearing (Vo and Strachan, 2008). The consequence of this is yet another barrier which women have to transcend to achieve gender equity.

On the other hand, it could be argued that the policy of renovation provides favourable opportunities for female academic staff to travel abroad to enrol in postgraduate degrees, including the doctoral degree. When these opportunities are realised, and students return to Vietnam with doctoral credentials from prestigious western 
universities, they are in a much better position to compete against male candidates whose doctorates have been awarded from a Vietnamese university (Funnel \& Dao, 2013). Although gender prejudices may still be manifest, the status of having studied abroad for a doctorate from a western university of international reputation compensates as an academic achievement of scholarly excellence that contributes to the international standing of the home university.

However, doctoral programs abroad in English speaking universities. often take longer than expected to complete. This being so, protracted extensions of candidature are not uncommon, due to cultural adjustment issues, acute stress, and the high standard of competency in English required to complete the degree. This being so, the extension of doctoral candidature can create a barrier of a more subtle kind for female students who study abroad. The problem of gender inequity that arises here is that :1) the time students spend abroad could have been used effectively to network for jobs in their own or other universities through employment as part time tutors or lecturers, thereby advancing their claim to already having had a strong record of teaching experience; 2) the time female doctoral students spend abroad means they have less time in chasing career success than their counterpart peers who have endeavoured to do this from the outset of their doctoral study at their home university. To make matters worse there is a Vietnamese policy issue of gender inequality that compels women to retire at 55 years of age, while men do not have to face compulsory retirement until the age of 60 . This means that women all have at least five years less to climb the ladder to success, and that women who study abroad face the same five-year loss as do women who study at home, but lose extra months or years in so far as they accumulate from any extensions of candidature. In essence, women have to be prepared to submit for promotion five years earlier than does a man in the hope of getting a promotion (Mai, 2007).

\section{Conclusion}

Empowering women in management and leadership is an essential goal that the Vietnamese government is admirably concerned to achieve. The number of females in the Vietnamese National Assembly has been reasonably high from 2002-2007, when compared to other countries in Asia. However, the graphs presented here show that for nearly a decade, from 2007 to 2016, the percentage of female members in the National Assembly has been declining. Despite the important legislation issued by the Vietnamese government on gender equity in both employment and education, the rate of equity improvement and progress toward women's leadership in tertiary education is not only slower than expected, but there still exists a considerable disparity in the percentage of women in tertiary leadership employment, where men occupy most of the executive positions.

Moreover, many households have been influenced by Confucianist stereotypical views of the inferiority of women and thus negatively informed and shaped the overall modality of familial relations for many centuries and have transmitted discriminatory perceptions about females from generation to generation. It is salutary to remind ourselves that the Confucianist philosophy of discrimination still persists and states unequivocally that "having sons are unambiguously preferred to having daughters "(Belanger, 2003). In addition, women in employment do not enjoy the same opportunities for employment and promotion as do men, and do not get much support from men when they are employed. In a more general context of this negative impact on women's goals towards higher education and executive leadership employment, there still exists a substantial inequity in regard to the way in which household chores and child rearing responsibilities are divided up between males and females, with males doing far less than females, despite intervention programs designed to rectify this imbalance. Moreover, in Vietnam there exists a large sector of the community which insists that household management and chores are to be considered much more suitable for women than men (Que, 1996).

In addition to the reasons mentioned above, there exists other causes that directly influence the leadership role of women in education. Consistent with the important reasons discussed above, it is clear that the social institutions which protect the vested interests of economic growth and promote the fiduciary goals of the market economy are based upon a form of epistemological patriarchy which derogates the status of women by supporting legislation which requires the compulsory retirement of women at 55, while gratuitously advantaging men with another five years before having to retire at age 60 .

Despite the noble efforts made by the Vietnamese government to support gender equity, the traditional conventions motivated by Confucianist philosophy and other ungrounded modalities of discrimination still stand as an impediment to equal opportunity for women and career development. The thread of gender prejudice has been woven tightly through the fabric of many societies, and not just in Vietnam, with its Confucianist foundations. In the final analysis there is a profound need to reveal prejudice wherever it is found, and whatever manner of discrimination it may be, e.g. racial, religious, sexual, or gender. Discrimination is a pathway to Depersonalisation; Depersonalisation leads to Dehumanisation, and in turn the loss of equal consideration of 
interest and Empathy. The Crusade against Discrimination depends on the instantiation of the foundational values that define the moral sensibility of our Humanity, just as the scale of Equity must serve the goal of reforming the inequitable institutional edifices within which justice should be weighed.

\section{References}

Asian Development Bank. (2002). Women in Vietnam. Manila: Regional and Sustainable Development Department and Mekong Department. Asian Development Bank.

Australia, J. (2013). Gender, Trade and Public Procurement Policy. Retrieved from http://knowledge.cwbusinesswomen.org/wp-content/uploads/2015/02/CommSec-Gender-trade-and-public-p rocurement-0714.pdf

Belanger, D., Oanh, K. T. H., Jianye, L., Thuy, L.T., \& Thank, P.V. (2003). Are sex ratios at birth increasing in Vietnam. Population, 58(2), 231-250. http://dx.doi.org/10.3917/pope.302.0231

Binh, D. T., Van, L. N., \& Khieu, N. L. (2002). Gia dinh Viet Nam va nguoi phu nu trong gia dinh (Vietnamese families and Women in the families). Hanoi: NXB KHXH.

Buchanan, R., \& Laura, R. (2012). Theo-critical feminism, mother nature and epistemological patriarchy. NOVA. The University of Newcastle's Digital Repository.

Carnoy, M., P. Loyalka, G. V. Androushchak \& A. Proudnikova. (2012). The Economic Returns to Higher Education in the BRIC Countries and Their Implications for Higher Education Expansion. HSE Papers, No. WP BRP 02/EDU/2012. Moscow: Higher School of Economics Research.

Cox, A. (2013). Human resource management in Vietnam. Managing Human Resources in Asia-Pacific, 20, 166.

Dollar, D., \& Gatti, R. (1999), Gender inequality, income, and growth: Are good times good for women? Policy research report on gender and development. (working paper series, no.1). The Word Bank Development Research Group/Poverty Reduction and Economic Management Network.

Frenier, M. D., \& Mancini, K. (1996). Vietnamese women in a Confucian setting: The causes of the initial decline in the status of East Asian women. In K. Barry (Ed.), Vietnam's women in transition. New York: Macmillan. http://dx.doi.org/10.1007/978-1-349-24611-3_2

Funnel, R., \& Dao, H. C. (2013). Journeys to the top: Women university rectors in Vietnam. Gender in Management, 28(5), 299-312. http://dx.doi.org/10.1108/GM-11-2012-0094

Goldin, C. (2013). A pollution theory of discrimination: male and female differences in occupations and earnings. In Human capital in history: The American record (pp. 313-348). University of Chicago Press.

Houtrat, F., \& Lemercinier, G. (1984). Hai Van: Life in a Vietnamese commune: Zed Books.

John, K., Loi, V. M., Jayakody, R., \& Huy, V. T. (2004). Gender roles in the family: Change and Stability in Vietnam. PSC Research Report. University of Michigan.

Laura, R., \& Buchanan, R. (2008). God, Freedom and Nature: transdisciplinary reflections on the discourse of religion and theory. In Laura, R. S., Buchanan, R. A. and Chapman, A. K. (Eds.), God, Freedom and Nature: Proceedings of the 2008 Biennial Conference in Philosophy Religion and Culture (p. 1.). Sydney, Publishing House: Body and Soul Dynamics.

Laura, R., \& Buchanan, R. (2012). God, freedom and nature: transdisciplinary reflections on the discourse of religion and theology| NOVA. The University of Newcastle's Digital Repository.

Laura, R., \& Chalender, R. (2012). Patriarchal theism. NOVA. The University of Newcastle's Digital Repository.

Laura, R.S., \& Ashton, J. (1991). Hidden Hazards. London Bantam.

Lord, L., \& Vinnicombe, S. (2010). Learning from experiences: A study of female academic leaders in Australia. In Rothstein, M. B., \& Burke, R. J. (Eds.), self-management and leadership development (pp. 447-463). Cheltenham, UK: Edward Elgar Publishing Limited. http://dx.doi.org/10.4337/9781849805551.00025

Mai, T. (2007). Co so ly luan va thuc tien cua cac giai phap tang cuong vai to doi ngu can bo nu trong hoat dong quan ly nha truong dai hoc. (Theoretical and Practical Bases to enhance women's role in university management: Theory and practice), Hanoi National University, Ha Noi.

MOET. (2013). Thong ke giao duc nam 2013 (Statistics of education in 2013). Retried from http://www.moet.gov.vn/?page=11.10 
Nguyen, L. T. (1995). Nho học ở Việt Nam [Confucianism in Viet Nam]. Ha Noi, Viet Nam: Education Publishing House.

Que, T. T., Uyen, V. N., \& Bang, N. T. (1999). Gender basic concepts and gender issues in Vietnam. Hanoi: Center for Gender Environment and Sustainable Development.

Tan, J. P., \& Mingat, A. (1992). Education in Asia: a comparative study of cost and financing. Washington DC: World Bank. http://dx.doi.org/10.1596/0-8213-2098-X

The National Assembly. (2006). Retrieved from https://www.wcwonline.org/pdf/lawcompilation/VietnamGenderEqualityLaw.pdf

Thomas, W. (2016). Proportion of female professors at $23 \%$ in 2015. Retrieved from https://www.destatis.de/EN/PressServices/Press/pr/2016/07/PE16_245_213.html

Tu, H., Forret, M., \& Sullivan, S. (2006). Careers in a non-Western context: an exploratory empirical investigation of factors related to career success of Chinese managers. Career Development International, 11(7), 580-593. http://dx.doi.org/10.1108/13620430610713454

UN. (2015). Transforming our world: the 2030 Agenda for sustainable development. Retrieved from http://www.un.org/ga/search/view_doc.asp?symbol=A/70/L.1\&Lang=E

UNDP. (2012). Nu dai bieu Quoc hoi o Viet Nam huong toi tuong lai (Female delegates in Vietnamese Congress toward future. Retrieved from http://lanhdaonu.vn/profiles/lanhdaonuvn/uploads/attach/1405667799_nudaibieuquochoiovietnamhuongtoi. pdf

UNESCO. (2013). Adult and Youth literacy, national, regional and global trends 1985 - 2015. Retried from http://www.uis.unesco.org/Education/Documents/literacy-statistics-trends-1985-2015.pdf

UNESCO. (2014). Higher education in Asia: Expanding out, expanding up. The rise of graduate education and university research. UNESCO Institute for Statistics, Canada. Retried from http://www.uis.unesco.org/Library/Documents/higher-education-asia-graduate-university-research-2014-en. pdf

USAID. (nd). Gender Equity and Female Empowerment. Fact sheet. Retrieved from http://www.usaid.gov/sites/default/files/documents/1861/USAID_Vietnam_Gender_Fact_Sheet_Eng.pdf

Vo, A.N., \& Strachan, G. (2008). Gender equity in a transforming economy. Paper presented at the Ninth International Women in Asia Conference.

Webster, J., \& Laura, R.S. (2016). Secularising the Sacred. The American University Press.

World Bank. (1995). Priorities and strategies education: a World Bank review. Washington DC: World Bank.

World Bank. (2001). Engendering development: Through gender equality in rights, resources and voice. New York: Oxford University Press.

World Bank. (2012). Put Higher Education to Work. Washington D.C.: The World Bank.

World Economic Forum. (2013). The Global Gender Gap Report 2013. Switzerland. Retrieved from http://www3.weforum.org/docs/WEF_GenderGap_Report_2013.pdf

Xie, Y., \& Hannum, E. (1996). Regional variations in earning inequality in reform-era urban China. American Journal of Sociology, 91, 950-992. http://dx.doi.org/10.1086/230785

\section{Copyrights}

Copyright for this article is retained by the author(s), with first publication rights granted to the journal.

This is an open-access article distributed under the terms and conditions of the Creative Commons Attribution license (http://creativecommons.org/licenses/by/4.0/). 